УДК 332.142

А. П. Аелеченко,

к. держ. упр., дочент, професоркафедри регіонального управління,

місиевого самоврядування та управління містом,

Начіональна академія державного управління при Президентові Украйни

ORCID ID: 0000-0002-0850-3724

DOI: $10.32702 / 2306-6814.2020 .13-14.92$

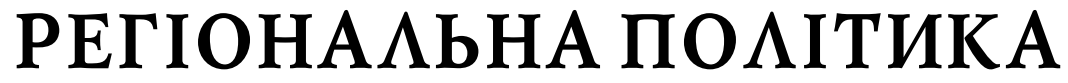 \\ ЯКК НАУКОВО-ПРИК АААНИЙ ФЕНОМЕН
}

\author{
A. Lelechenko, \\ $\mathrm{PhD}$ in Public Administration, Associate Professor, Professor of the Department of Regional Governance, \\ Local Self-Government and Urban Management, National Academy for Public Administration under the President of Ukraine
}

\section{REGIONAL POLICY AS A SCIENTIFIC AND APPLIED PHENOMENON}

Устатті окреслено специфіку теоретико-методологічного підходудо дослідження регіональної політики як науково-прикладного феномену. Поняття "регіональна політика" розглядається як офіційно державне та наукове визначення, що дало змогу виділяти загальнодержавну $i$ регіональну частини. Упершому випадку можна говорити про політику, що має державний статус, а в другому мова йде про регіональну політику самих регіонів, у тому числі і щодо своїх територій, яка формується і здійснюється "зверху вниз". Такий підхід кореспондує і з іншими підходами до розгляду поняття "регіональна політика", яку науковці визначають як спектр соціально-економічних, етно-демографічних, політичних, управлінських та інших процесів і проблем на тій підставі, що всі вони мають територіальну прив'язку. Аналіз наукових розвідок довів, що методологічним обертоном дослідження є синтез парадигм, які стосуються зовнішнього $i$ внутрішнього підходів до визначення регіональної політики як складової частини єдиної державної політики, перша з яких використовує макроекономічні інструменти для посилення синергії національного економічного простору і надання регіонам додаткових можливостей для розвитку, а друга - для вирішення місцевих завдань у розрізі регіональних особливостей.

Виявлено конкретні акцентуації щодо визначення феномену дефініції "регіональна політика", яку конкретизовано і представлено як сукупність цілей, завдань, намірів і дій державних, регіональних і муніципальних органів влади, а також інших суб'єктів господарювання, спрямованих на створення умов для саморозвитку територій, досягнення певної просторової соціально-економічної та іншої рівноваги країни з урахуванням дотримання загальнонаціональних, регіональних, субрегіональних та локальних інтересів.

The article identifies the specific of theoretical and methodological approach to the study of regional politics as a scientific and applied phenomenon. The concept of "regional policy" is considered as an official state and scientific definition, which allowed us to distinguish between national and regional parts. First of all, we can talk about policy that has a state status, and the second we analyze the regional policy of regions themselves, including policy that has a state status". This approach also corresponds to other approaches to considerate the concepts of "regional policy", which scientists define as a spectrum of socio-economic, ethno-demographic, political, managerial and other processes and problems on the grounds that they have a territorial connection. Analysis of 
research has shown that the methodological overtone of the study is a synthesis of paradigms related to external and internal approaches to defining regional policy as part of a single public policy, the first of which uses macroeconomic tools to strengthen synergies and provide additional opportunities for development and the second one to solve local problems in terms of regional characteristics. Concrete accentuations are identified to determine the phenomenon of definition "regional policy", which are specified and presented as a set of goals, objectives and actions of state, regional and municipal authorities, as well as other business entities aimed at creating conditions for selfdevelopment of territories, achieving a certain spatial social-economic and other equilibrium of the country, taking into account the observance of national, regional, sub-regional and local interests.

The novelty of this concept demonstrates a multidimensional and multifaceted phenomenon that affects the multidirectional interests of individuals, their territorial, economic, political and other communities, authorities and management, economic entities and genetically connects and implements economic, social, environmental, natural resource, innovative, infrastructural, ethnodemographic, socio-political and other relations.

Ключові слова: регіональна політика, регіон, державна регіональна політика, механізм регіональної політики, регіональний розВиток.

Key words: regional policy, region, state regional policy, regional policy mechanism, regional development.

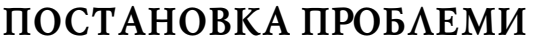

Регіональна політика як інструмент державного регулювання активно розвивається з другої половини XX ст. і продовжує набирати наукових та практичних обертів під впливом інтернаціоналізації та локалізації суспільного життя. Усе це спричиняє делегування частки державного суверенітету на наддержавний і регіональний рівні та є новим імпульсом для стрімкого розвитку регіональних досліджень.

\section{АНА $\Lambda$ I ОСТ АНHIX АОС $А$ ОЖЕНЬ} І ПУБ $\Lambda$ ІКАЦІЙ

В останні роки у працях багатьох вітчизняних та зарубіжних науковців знайшли відображення теоретичні положення та методологічні принципи регіональної політики. Вагомий внесок у дослідження даного питання зробили: А. Голіков, Б. Данилишин, О. Дьомін, М. Долішній, Н. Казакова, В. Керецман. Т. Кравченко, М. Лендьел, О. Мринська, М. Пістун, І. Семененко, Д. Стеченко, А. Топчієв, В. Фатеев, Н. Чумаченко та ін. Проте аналіз наукових підходів до трактування регіональної політики потребує подальшого комплексного дослідження.

\section{META CTATTI}

Метою статті $є$ поглиблення теоретико-методологічних засад щодо конкретизації визначення регіональної політики як науково-прикладного феномену.

\section{ВИК ААА ОСНОВНОГО МАТЕРІААУ АОС АІАЖЕННЯ}

На сучасному етапі розвитку регіоналістики спостерігається підвищена увага до чіткого обгрунтування та поглиблення теоретико-методологічних засад регіо- нальної політики. Відповідно актуалізується проблема нерівномірного регіонального розвитку, що відноситься до фрундаментальних загальносвітових процесів. I, як певний френомен, обумовлена не тільки різноманітністю фрізико-географрічних, геополітичних, економічних, історичних та багатьох інших умов, але і тенденціями концентрації і деконцентрації продуктивних сил. Тому практично всі країни вживають заходів щодо стримування міжрегіональних економічних і соціальних відмінностей, здійснюючи тучи іншу регіональну політику.

Регіональна політика в Україні вимагає радикального оновлення, пошуку і вибору нової парадигми цілісної системи базових положень, наукових поглядів, вихідних принципів, уявлень, правил, переконань, які логічно взаємопов'язані між собою і відображають соціальні, економічні, політичні та інші суспільні процеси. Сьогодні в галузі науки "Державне управління" поки що не вдалося узагальнити результати багатолітніх теоретичних дискусій і дати найбільш ємне визначення регіональної політики. Сформувалося кілька підходів до трактувань даного поняття.

Одні вчені розуміють регіональну політику як "складову частину державної політики, завданням якої $€$ територіальне використання основних економічних інструментів і видів діяльності". Тобто "регіональна політика виступає складовою частиною політики держави, яка направлена на організацію території держави відповідно до прийнятої стратегії розвитку. Передумовами регіональної політики є структурна неоднорідність території держави в її природно-географічному, ресурсному, економічному, соціальному, етнічному і політичному аспектах. Все це зобов' язує вживати які-небудь дії в межах внутрішньої політики, беручи до уваги інтереси регіонів" [10, с. 23, 73]. 
Інші вважають, що в офріційному викладі державну регіональну політику варто представити як систему заходів, що здійснюються органами виконавчої влади та органами місцевого самоврядування щодо ефективного управління економічним і соціальним розвитком України та її регіонів Автономної Республіки Крим, областей, міст Києва і Севастополя. [1, с. 19].

Натомість, у науковому поданні, регіональна політика це розробка і реалізація в державних масштабах системи заходів щодо збалансованого соціально-економічного розвитку територій, створення сприятливих передумов для функціонування господарюючих суб'єктів, а також належних соціальних і економічних умов для життєдіяльності населення [1, с. 19].

Узагальнюючи сутність даних визначень можна констатувати наступне: в трактуванні регіональної політики, в її структурі слід виділяти загальнодержавну і регіональну частини. У першому випадку можна говорити про політику, що має державний статус, а в другому мова йде про регіональну політику самих регіонів, у тому числі і щодо своїх територій, яка формується і здійснюється "зверху вниз". 3 цією позицією цілком корелює визначення регіональної політики як діяльності держави, спрямованої на забезпечення ефективного й комплексного соціально-економічного розвитку окремих територій країни - її регіонів. Таким чином, регіональна політика має два головних вектори щодо своєї розробки та реалізації - "згори", від центру, який обгрунтовує засади й принципи державної регіональної політики, i "знизу", від конкретних територій, де напрацьовують практичний досвід регіонального планування та господарювання [7, с. 95 ].

Такий підхід кореспондує і з іншими підходами до розгляду поняття "регіональна політика", яку науковці визначають як систему цілей і дій, що спрямовані на реалізацію інтересів держави щодо регіонів та внутрішніх інтересів самих регіонів, яка реалізується за допомогою методів, що враховують історичну, етнічну, соціальну, економічну та екологічну специфіку територій. Таке визначення досить повно окреслює існуюче уявлення про регіональну політику, а головне, вказує на можливість створення прийнятного як для держави, так і для її регіонів механізму взаємодії, який враховуватиме особливості окремих територій та сприятиме найкращому використанню наявних ресурсів [3].

Ю. Наврузов вважає, що "сучасна регіональна політика має бути визначена як така діяльність держави, що спрямована на адміністративно-економічну оптимізацію регіональної структури країни та відносин між центром і територіями з метою забезпечення балансованого розвитку за рахунок максимально ефективного використання наявних внутрішніх і залучення зовнішніх ресурсів" [5, с. 43].

Можна навести більш лапідарне трактування: "регіональної політики як державних заходів щодо перерозподілу ресурсів між регіонами країни заради заданих цілей" [8, с. 38].

Квінтесенцією даних визначень $є$ ідея, що поряд із державою, регіони, в особі своїх лідерів, регіональних органів влади, мають власну ціннісну систему, відповідну економічну, політичну та інтелектуальну міць, здатність самостійно і під свою відповідальність прий- мати і реалізовувати ті чи інші рішення щодо адміністративних одиниць, які знаходяться під їх юрисдикцією.

Вважаємо позитивною думку окремих науковців [1, c. 254], на переконання яких регіональна політика - це розробка і реалізація в державних масштабах системи заходів щодо збалансованого соціально-економічного розвитку територій, створення сприятливих передумов для функціонування господарських об'єктів, а також належних соціальних і економічних умов для життєдіяльності населення. Показово, що в сучасну епоху регіональна політика $€$ складовою частиною національної стратегії соціально-економічного розвитку переважної частини держав світу.

Водночас окремо слід відзначити західні методологічні підходи, які еволюціонували на різних етапах розвитку. Слушними у цьому контексті $є$ представлені для обговорення пропозиції, запропоновані А. Сапожніковим, цитуючи які, виділено чотири етапи сучасної історії регіональної політики: перший етап - 30-ті роки, коли регіональні заходи по-справжньому практикувалися лише в західній Європі і США в додаток до антикризових реформ; на другому етапі (з кінця 40-х до кінця 50-х рр.) - розширюється коло країн Західної Європи, які приділяють увагу регіональним заходам; з кінця 50-х років до економічного спаду 1974-1975 рр. необхідність проведення регіональної політики визнається пріоритетним напрямом діяльності держави, вдосконалюється інструментарій регіональної політики, формуються системи регіонального програмування; на четвертому етапі, який розпочався з середини 70-х років, у зв'язку із загостренням кризових явищ пріоритет цілей регіонального характеру почав знижуватися, у результаті чого на перший план поставлено завдання модернізації промисловості та виробничого апарату [9, с. 35].

На наш погляд, при вивченні зарубіжного досвіду доцільно, піддавати грунтовному аналізу всі напрями регулювання територіального розвитку центральними органами влади. Адже регіональна політика неминуче спирається на регіональне планування; від масштабів перерозподілу бюджетних доходів між регіонами (тобто від особливостей міжбюджетних відносин) залежить здатність регіональної влади здійснювати бюджетні інвестиції, і тим самим впливати на економічний розвиток своїх територій. Інакше кажучи, чим більшими є масштаби міжбюджетного перерозподілу доходів, тим меншими можуть бути масштаби самої регіональної політики і навпаки. Ще один важливий аспект ступінь децентралізації повноважень, від якого залежать особливості здійснюваної регіональної політики, точніше характер участі регіональної влади (влади на місцях) у розробці і реалізації такої політики.

У цьому аспекті заслуговує уваги запропоноване в енциклопедії державного управління Ю. Давидовою визначення регіональної політики ЄС, яка, на думку дослідниці, "грунтується на політичному принципі, заможні країни та регіони забезпечують солідарність із біднішими країнами та регіонами, а також на економічному принципі, нижчі обсяги виробництва у бідних країнахучасницях і регіонах або в країнах і регіонах з високим рівнем безробіття $є$ втратою потенціалу й можливостей для ЄС в цілому. Регіональна політика ЄС є солідарною, спрямованою на допомогу всієї спільноти найменш 
розвиненим регіонам у подоланні їх відставання та відкритою, тому що її результати прозорі для всіх громадян Європи, які отримали допомогу з працевлаштування або перекваліфікації. Основна мета регіональної політики ЄС передбачає забезпечення ефективного використання потенціалу територій та створення сприятливого середовища для їх зовнішньої підтримки, сприяння гармонійному та сталому розвитку країни, підвищенню конкурентоспроможності регіонів як основи національної конкурентоспроможності, заохочення інноваційних підходів і зменшення суттєвих дисбалансів у рівнях її розвитку" [2, с. 313-314].

Узагальнюючи сутність таких визначень, можна констатувати так: державна регіональна політика - це політика держави щодо політичного, правового, соціального та економічного розвитку країни в просторовому (регіональному) аспекті, яка відображає як взаємовідносини між державою і регіонами, так і взаємини регіонів між собою. Вона може проводитися на трьох рівнях: 1) державному, тобто з активною участю центру в регіональному розвитку; 2) регіональному всередині регіональний розвиток на основі наявних повноважень і коштів регіонів; 3) локальному політика органів місцевого самоврядування (в зарубіжних європейських країнах муніципальна політика).

Фактично для побудови унітарної і водночас децентралізованої демократичної держави регіональна політика, як слушно зазначає М. Пістун, має сприяти вирішенню двох основних завдань розробці та реалізації системи раціонального використання інтегрального потенціалу території України і надання регіонам можливостей для переходу на саморозвиток і самоврядування, формування в них ринкових відносин із урахуванням своїх регіональних особливостей [6, с. 117]. Водночас методологія регіональної політики, механізм та інструменти її реалізації повинні бути спрямовані на посилення тих позитивних тенденцій регіонального розвитку, які обумовлені, як внутрішніми, так і зовнішніми фракторами, зокрема, необхідно враховувати кон'юнктуру національного і світового ринку, науково-технічний прогрес та інновації, зміни в конкурентних позиціях держави в умовах інтернаціоналізації господарської діяльності і глобалізації [1, с. 36].

Відповідно через розвиток сучасних методологічних підходів до розробки і здійснення регіональної політики, актуалізується питання її імплементації на принципах ефективності, комплексності, послідовності, гнучкості, пріоритетності, перспективності [4, с. 6]. Саме ці принципи мають генерувати успішну реалізацію та результативність заходів щодо регіонального розвитку, а також бути релевантними тим важелям і інструментам регіональної політики, які б відповідали потребам регіонів.

Під час здійснення регіональної політики виділяють і суб'єкт-об'єктні зв' язки, де в якості суб'єктів регіональної політики виступають органи державного управління різних ієрархічних рівнів і органи місцевого самоврядування, а також великі виробничі корпорації, міжрегіональні асоціації. При цьому об'єктами є різноманітні економічні, соціальні та політичні явища і процеси, які мають місце в певних адміністративно-територіальних утвореннях.
Екстраполюючи отримані результати на сучасні політико-правові реалії в Україні, треба визнати, що змістовна сутність і спрямованість регіональної політики напряму залежить від рівня соціально-економічного розвитку держави. У країнах, що мають високий рівень економічного розвитку, пріоритетною $є$ соціальна сфера і основний акцент робиться на підвищенні якості життя і його вирівнюванні в регіональному розрізі. У країнах з більш низьким рівнем превалюють економічні пріоритети. У них при реалізації регіональної політики головна увага приділяється розвитку виробничого потенціалу, підвищенню продуктивності праці, ефективного використання природно-ресурсного та трудового потенціалу регіонів, розвиток інфрраструктури та ін. [1, с. 35].

Аналіз наукових розвідок довів, що методологічним обертоном дослідження є синтез парадигм, які стосуються зовнішнього і внутрішнього підходів до визначення регіональної політики як складової частини єдиної державної політики, перша з яких використовує макроекономічні інструменти для посилення синергії національного економічного простору і надання регіонам додаткових можливостей для розвитку, а друга для вирішення місцевих завдань у розрізі регіональних особливостей.

\section{ВИСНОВКИ 3 ПРОВЕАЕНОГО АОС АІАЖЕННЯ І ПЕРСПЕКТИВИ ПОАА НАПРЯМІ}

Зважаючи на останні дослідження та публікації, виявлено конкретні акцентуації щодо визначення феномену десініції "регіональна політика", яку в нашому розумінні можна конкретизувати і представити як сукупності цілей, завдань, намірів і дій державних, регіональних і муніципальних органів влади, а також інших суб'єктів господарювання, спрямованих на створення умов для саморозвитку територій, досягнення певної просторової соціально-економічної та іншої рівноваги країни з урахуванням дотримання загальнонаціональних, власне регіональних, субрегіональних та локальних інтересів.

Новизна такої дефініції регіональної політики в порівнянні з раніше сорормульованими полягає в тому, що, по-перше, суб'єктом регіональної політики можуть виступати конкретні представники влади всіх трьох місцевих рівнів управління, а також різні громадські організації (асоціації, об'єднання, спілки, групи), фрізичні особи, які мають право висловлювати регіональні інтереси, здатні представляти, захищати і реалізовувати їх як суб'єкти правовідносин.

По-друге, загальним об'єктом регіональної політики $€$ власне самі регіони, зокрема цілісність територіального утворення, спільність природних, соціальноекономічних, науково-культурних та інших умов, що сприяють саморозвитку території.

По-третє, регіональна політика переслідує реалізацію таких основних цілей як створення умов для задоволення суспільних потреб населення, вирівнювання рівнів соціально-економічного розвитку регіонів, дотримання територіальної справедливості і збереження територіальної цілісності держави. На наше глибоке переконання, діалектична єдність такої тріади демонструє багатоаспектне і багатопланове явище, яке прямо або опосередковано зачіпає множинні і різноспря- 
мовані інтереси окремих людей, їх територіальних, господарських, політичних та інших спільнот, органів влади та управління, господарюючих суб'єктів і генетично пов'язує та реалізує економічні, соціальні, екологічні, природно-ресурсні, інноваційні, інфрраструктурні, етнодемографрічні, суспільно-політичні та інші відносини.

Натомість потребують подальшого дослідження питання регіонотворення та реалізації ефективної і дієвої регіональної політики в Україні у контексті започаткованої і здійснюваної адміністративно-територіальної реформи. Країні гостро необхідна нова регіональна політика з чітко сформульованими цілями, чіткими завданнями і дієвими механізмами реалізації, що детермінує у собі цілі сталого розвитку регіонів, зокрема екологічні, соціальні та економічні складники.

\section{Література:}

1. Голиков А.П. Региональная политика и экономическое развитие: европейский контекст: учебное пособие // Н.А. Казакова, Ю.Г. Прав. Х.: РИО ХНУ имени В.Н. Каразина. - 2009. - 270 с.

2. Енциклопедія державного управління: у 8 т. / Нац. акад. держ. упр. при Президентові України; наук.ред. колегія: Ю. В. Ковбасюк (голова) та ін. К.: НАДУ, 2011. - Т. 5: Територіальне управління / наук.-ред. колегія: О.Ю. Амосов, О.С. Ігнатенко (співголова) та ін. Харківський регіональний інститут державного управління Національної академії державного управління при Президентові України. - Х.: Вид.-во ХарРІДУ "Магістр", 2011. - 408 c.

3. Кравченко Т.В. Теоретичні засади державної регіональної політики [Електронний ресурс] // Державне будівництво, 2009. - № 2. - Режим доступу: http:/ /www.nbuv.gov.ua/e-journals/DeBu/2009-2/doc/1/ 07.pdf

4. Мрінська О.В. Регіональна політика в країнах Європейського Союзу і можливостіїї досвіду в Україні (суспільно-географрічне дослідження): автореф. дис.... к. географ. н.; Інститут географії НАН України. Київ, 2005. - $20 \mathrm{c}$.

5. Наврузов Ю. Регіональна політика в Україні: проблеми, принципи, перспективи / / Управління сучасним містом. - 2001. - № 1-3 (1). - С. 41-50.

6. Пістун М.Д. Основи теорії суспільної географії. К.: Вища школа, 1996. - 231 с.

7. Регіональна політика та управління у країнах Європи: матеріали до навчального курсу / упоряд. М.О. Лендьел, В.Ю. Керецман. Ужгород: б. в., 2001. $248 \mathrm{c}$.

8. Семененко И. Группы интересов в Европейском Союзе: региональный аспект / / Мировая экономика и международные отношения. - 1998. - № 4. - С. 38.

9. Фатеев В.С. Региональная политика: теория и практика. Европ. гуманит. ун-т. Минск: ЕНU, 2004. - 478 с.

10. Чумаченко Н.Г. Проблемы региональной политики в Украине / / Людина і політика. - 1999. - № 3. С. $50-56$.

\section{References:}

1. Golikov, A.P. Kazakova, N.A. and Prav, Ju.G. (2009), Regional'naja politika i jekonomicheskoe razvitie: evropejskij kontekst [Regional Policy and Economic
Development: A European Context], RIO HNU imeni V. N. Karazina, Kharkiv, Ukraine.

2. Kovbasiuk, Yu. V. Amosov, O. Yu. and Ihnatenko, O. S. (2011), Entsyklopediia derzhavnoho upravlinnia [Encyclopedia of Public Administration], Vyd.-vo KharRIDU "Mahistr", Kharkiv, Ukraine.

3. Kravchenko, T. V. (2009), "Theoretical principles of state regional policy", Derzhavne budivnytstvo, [Online], vol .2, available at: http://www.nbuv.gov.ua/e-journals / DeBu/2009-2/doc/1/07.pdf (Accessed 29 May 2020).

4. Mrins'ka, O.V. (2005), "Regional policy in the European Union and the possibilities of its experience in Ukraine (socio-geographical study)", Ph.D. Thesis, Instytut heohrafii NAN Ukrainy, Kyiv, Ukraine.

5. Navruzov, Yu. (2001), "Regional policy in Ukraine: problems, principles, prospects", Upravlinnia suchasnym mistom, vol. 1-3 (1), pp. 41-50.

6. Pistun, M.D. (1996), Osnovy teorii suspil'noi heohrafii [Fundamentals of the theory of social geography], Vyscha shkola, Kyiv, Ukraine.

7. Lend'el, M. O. and Keretsman, V. Yu. (2001), Rehional'na polityka ta upravlinnia u krainakh Yevropy [Regional policy and governance in European countries], Uzhhorod.

8. Semenenko, I. (1998), "Interest groups in the European Union: regional dimension", Mirovaja jekonomika i mezhdunarodnye otnoshenija, vol. 4, pp. 38.

9. Fateev, V.S. (2004), Regional'naja politika: teorija i praktika [Regional policy: theory and practice], Evrop. gumanit. un-t. EHU, Minsk, Belorussia.

10. Chumachenko, N. H. (1999), "Problems of regional policy in Ukraine", Liudyna i polityka, vol. 3, pp. 50-56. Cтаття надійшла до редакиї 08.07.2020 p.

\section{www. economy.nayka.com.ua} Електронне фахове видання

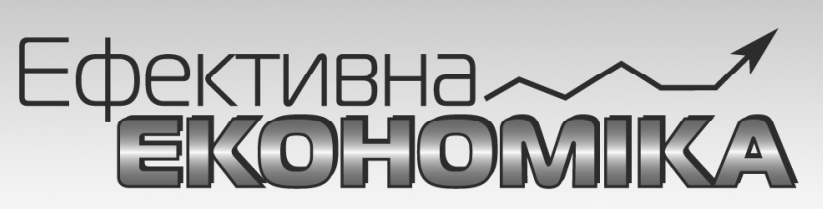

\section{Виходить 12 разів на рік}

Журнал включено до переліку наукових фахових видань України з ЕКОНОМІЧНИХ НАУК (Категорія «Б»)

Спеціальності - 051, 071, 072, 073, 075, 076, 292

e-mail:economy_2008@ukr.net

тел.: (044) 223-26-28

(044) $458-10-73$ 